\title{
Problematic of Clandestine Induced Abortions in Three Maternity Hospitals of Chad
}

\author{
Lhagadang Foumsou, 1,2*, Guira Daniel Dangar1,2, Ouchémi Choua ${ }^{3}$, Sadjoli Damthéou,2, \\ Bray Madoué Gabkika1, Olivier Moalloum Tarda4, Rostand Dounou Njiki ${ }^{4}$
}

\author{
${ }^{1}$ Department of Gynecology and Obstetrics, University of N’Djamena, N'Djamena, Chad \\ ${ }^{2}$ N'Djamena Mother and Child Hospital, N’Djamena, Chad \\ ${ }^{3}$ Department of Surgery, University of N'Djamena, N'Djamena, Chad \\ ${ }^{4} \mathrm{UNFPA}$, City, Chad \\ Email: ^foumlhaga@gmail.com
}

How to cite this paper: Foumsou, L., Dangar, G.D., Choua, O., Damthéou, S., Gabkika, B.M., Tarda, O.M. and Njiki, R.D. (2017) Problematic of Clandestine Induced Abortions in Three Maternity Hospitals of Chad. Open Journal of Obstetrics and $G y$ necology, 7, 937-943.

https://doi.org/10.4236/ojog.2017.79094

Received: July 24, 2017

Accepted: August 28, 2017

Published: August 31, 2017

Copyright (C) 2017 by authors and Scientific Research Publishing Inc. This work is licensed under the Creative Commons Attribution International License (CC BY 4.0).

http://creativecommons.org/licenses/by/4.0/

\begin{abstract}
Background: In the world, induced abortion constitutes a preponderant cause of morbidity and maternal mortality, more particularly in developing countries. In these countries, the prevalence of contraception remains low, and situation makes the bed of unwanted pregnancies leading easily to the induced abortions. The objective was to determine frequency of clandestine induced abortions and to know the motivations of women that practice these abortions in order to find a solution to minimize this practice. Patients and method: We conducted a prospective, descriptive and multicenter survey for three months from November $1^{\text {st }}, 2015$ to January $31^{\text {st }}, 2016$ achieved at N'Djamena Mother and Child hospital which is national reference structure in terms reproduction health, Moundou Regional Hospital and Abéché Regional Hospital about the epidemiological aspects and complications clandestine induced abortions. The population of survey was constituted of patients admitted in a maternity of these hospitals for clandestine induced abortion. Every patient having practiced a documented induced abortion and having agreed to participate in the survey was included. Results: During the survey period, we recorded 94 cases of clandestine induced abortions among 2759 deliveries giving a frequency of $3.4 \%$. The age group between $20-24$ years was the most represented with $42.7 \%$. The average age was 25.4 years, with the extremes ranging from 15 to 42 years. Singles (66\%) dominated marital status. Sixty patients (63.9\%) were of secondary. These patients were for the most part students or pupils $(55.3 \%)$. Concerning the parity, nulliparous were the most numerous to practice the abortion (40.5\%). More than half our patients (58.7\%) knew no contraceptive method. The principal reason evoked to realize the abortion was further studies (38.2\%). Means of abortion most used was
\end{abstract}


the misoprostol (36 cases that is $38.2 \%$ ). In this series, we observed 29 cases of complications, which is $30.8 \%$. The complications were dominated by the anaemia (62.1\%). Conclusion: The clandestine induced abortion is a frequent situation in the Chad and is cause of numerous complications.

\section{Keywords}

Clandestine Induced Abortion, Motivations, Complications, Maternity, Chad

\section{Introduction}

In the world, induced abortion constitutes a preponderant cause of morbidity and maternal mortality, more particularly in developing countries [1]. According to the World Health Organization, on the 42 million abortions a year worldwide, 21.6 millions are at risk among which $95 \%$ in developing countries [2]. In Africa prevalence of modern contraception is $22 \%$, while remaining lower than $10 \%$ in its central part [3]. In Chad, modern contraceptive prevalence is $3 \%$, which remains particularly insignificant to satisfy the needs [4]. This situation makes the bed of unwanted pregnancies leading easily to the induced abortions. Almost all these abortions, carried out in violation of legislation, are secret and practiced in an inadequate sanitary environment by people insufficiently or not qualified [1]. Approximately 47,000 women die a year from complications of this practice. However, these complications can be avoided by the access to education, contraception and services to have an abortion [2]. This work had objective to determine frequency of clandestine induced abortions and to know the motivations of women that practice these abortions in order to find a solution to minimize this practice.

\section{Patients and Methods}

It was a prospective, descriptive and multicenter survey for three months from November $1^{\text {st }}, 2015$ to January 31 ${ }^{\text {st }}, 2016$ achieved at N’Djamena Mother and Child hospital which is national reference structure in terms reproduction health, Moundou Regional Hospital and AbéchéRegional Hospital about the epidemiological aspects and complications clandestine induced abortions.

The population of survey was constituted of patients admitted in a maternity of these hospitals for clandestine induced abortion.

Studied variables were age, marital status, profession, parity, knowledge on contraceptive methods, motivations to practice the abortion, means used to practice abortion, type of complication, management and prognosis. Every patient having practiced a documented clandestine induced abortion by interrogation and having agreed to participate in the survey was included. All patients admitted for threatened abortion, miscarriage, suspicion of ectopic pregnancy and those having refused to participate were not included in the study. 
The sample size was calculated using Lorenz formula:

$$
\mathrm{N}=\frac{\mathrm{Z}_{\mathrm{a}}^{2} \mathrm{PQ}}{\mathrm{D}^{2}}
$$

(where: $\mathrm{N}=$ acceptable sample size in each group [calculated value $=96.04$ ]; $\mathrm{a}=$ level of statistical significance; $Z_{a}=$ normal distribution value $=1.96$ for $a=0.05$; given thatprevalence of clandestine induced abortions in Chad is unknown, $\mathrm{P}=$ $50 \% ; \mathrm{Q}=1$ - P; D = degree of accuracy = 10\%). The minimum acceptable sample size was 97 patients.

For this survey, we obtained the agreement of the national Ethics Committee, Director of N'Djamena Mother and Child hospital, Moundou Regional Hospital, Abéché Regional Hospital and the informed consent of the patients. Data were analyzed using SPSS18.0.

\section{Results}

During the survey period, we recorded 94 cases of clandestine induced abortions among 2759 deliveries giving a frequency of $3.4 \%$ (Table 1).

The age group between 20 - 24 years was the most represented with $42.7 \%$. The average age was 25.4 years, with the extremes ranging from 15 to 42 years. Singles $(66 \%)$ dominated marital status. Sixty patients $(63.9 \%)$ were of secondary. These patients were for the most part students or pupils (55.3\%). Concerning the parity, nulliparous were the most numerous to practice the abortion (40.5\%).

Table 1. Social and epidemiologic characteristics.

\begin{tabular}{ccc}
\hline Social and Epidemiologic Characteristic & number $=94$ & $\%$ \\
\hline Age (year) & 12 & 12.7 \\
$14-19$ & 40 & 42.7 \\
$20-24$ & 28 & 29.8 \\
$25-29$ & 8 & 8.5 \\
$30-34$ & 6 & 6.3 \\
35 and more & & \\
Marital status & 62 & 66 \\
Singles & 12 & 12.7 \\
Married & 20 & 21.2 \\
Divorced & & \\
Schooling & 6 & 6.3 \\
No schooled & 12 & 12.7 \\
Primary & 60 & 63.9 \\
Secondary & 16 & 17.1 \\
University & & \\
Profession & 18 & 19.1 \\
Housewives & 52 & 55.3 \\
Pupils/Students & 24 & 25.6 \\
officials/salaried & & \\
Parity & 38 & 40.5 \\
Nulliparous & 20 & 21.2 \\
Primipara & 14 & 14.9 \\
Paucipara & 10 & 10.6 \\
Multipara & 12 & 12.8 \\
Grand multipara & & \\
\hline & & \\
\hline
\end{tabular}




\subsection{Knowledge on the Contraceptive Methods}

More than half our patients (58.7\%) knew no contraceptive method. Only 41.3\% declared to know one or several contraceptive methods.

\subsection{The Motivations of the Patients}

The principal reason evoked to realize the abortion was further studies (38.2\%), followed by the pregnancy outside of marriage (29.8\%). In $8.5 \%$ of the cases, the abortion was practiced for frequent pregnancy (Table 2).

\subsection{The Means Used}

Means of abortion most used was the misoprostol (36 cases that is $38.2 \%$ ), followed by the syntocinon (18 cases, that is $21.2 \%$ ). A not insignificant proportion (14 cases that is $14.8 \%$ ) used the honey. Other used means included the manual intra-uterine aspiration (11.2\%), dilation and curettage (8.3\%) and the chloroquine (6.3\%).

\subsection{Complications of Clandestine Induced Abortion}

In this series, we observed 29 cases of complications, which is $30.8 \%$. The complications were dominated by the anaemia $(62.1 \%)$ followed by the endometritis (13.7\%). We registered one case (1/94 case) of death that $2.1 \%$ lethality rate. This patient died in a table of septic shock (Table 3).

Table 2. Distribution of induced abortions according to the reasons given.

\begin{tabular}{ccc}
\hline Motivations & N & $\%$ \\
\hline Studies & 36 & 38.2 \\
Pregnancy outside of marriage & 28 & 29.8 \\
Accidents of life & 12 & 12.8 \\
Religion & 10 & 10.7 \\
Frequentpregnancies & 8 & 8.5 \\
Total & 94 & 100
\end{tabular}

Table 3. Distribution of the patients according the complications of induced abortion.

\begin{tabular}{ccc}
\hline Type of complication & N & $\%$ \\
\hline Anaemia & 18 & 62.1 \\
Endometritis & 4 & 13.7 \\
Retained placenta & 3 & 10.3 \\
Pelviperitonitis & 2 & 6.9 \\
Uterine perforation & 1 & 3.4 \\
Death & 1 & 3.4 \\
Total & 29 & \\
\hline
\end{tabular}




\section{Discussion}

The frequency of abortions caused in this series is $3.4 \%$. This rate is near to those reported by several series in Africa to the South of Sahara [5] [6] [7] [8] [9].

We found in this study that, the adolescent and the young women are subject to the induction abortion. The average age of patients was of 25.4 years and the edge age most represented was that from 20 to 24 years (42.7\%). This age bracket is the most underlined by the African studies [5] [9] [10] [11]. This situation could be explained by an early sexual activity of the young people especially since they do not use contraceptive method [3].

The majority of patients was singles (66\%). This result joins the data of literature that report a predominance of inducted abortions among the single women [5] [7] [10] [12] [13]. It could be explained by the fact that a pregnancy outside of marriage is a taboo in our societies and forbidden by the different religions, by the dread to parents and the refusal of paternity.

In addition, according WHO the poverty is considered as being a factor of induced abortion in developing countries [2].

The patients of the secondary level represented $63.8 \%$ cases in this study. This could be explained by the desire to continue the studies, the situation of these maternities in large cities where there are several schools and the disregard of contraceptive methods by these patients.

Nulliparous represented almost half of cases in this series. Nayama M [5] in Niamey in Niger, Laghzaoui O [7] in Meknes in Morocco and Abauleth R [11] in Abidjan in Ivory Coast relate a predominance of nulliparous in their studies respectively of $56.95 \%, 74.9 \%$ and $62.2 \%$. This could be explained by financial problems, the dread to parents and the desire to pursue the studies because the childbirth would constitute an additional burden, which might hinder good progress of studies.

The main reason mentioned to practice the abortion was the continuation of studies (38.2\%) followed by the pregnancy outside marriage (30.4\%). Several studies [5] [6] [9] [10] note a predominance of induced abortions among pupils and the students for motive for continuation of studies while the existence of a child prevents them from it. In Togo and in Gabon, will to continue studies represented respectively $28.03 \%$ and $21 \%$ of the motives [13] [14]. The partner or the spousal would play an important role in the practice of the abortion by refusing the paternity and the responsibility there relative. Rakotondraisoa [8] in Antananarivo in Madagascar, Benié Bi Vroh [12] in Abidjan in Ivory Coast and Nlomé-Nzé [14] in Libreville in Gabon underline as main reason to cause the abortion the financial problems. According to Fourn in Parakou in Benin, the motive to practice the abortion was the fear of the reactions of parents in 35\% cases [15]. The means of abortion most used was the misoprostol (36 cases that is $38.2 \%)$. Several African series report the misoprostol as the abortion means most used [8] [9] [10]. In Nigeria, Fawole reports a utilization rate of misoprostol of $66.2 \%$ [16]. The abortive power of this drug is known by the general pop- 
ulation, from which the trend at the self-medication in the clandestine abortion. The accessibility by the illicit sale of this drug exacerbates this situation. However, other African series find as abortion method the herbal decoctions, potassium permanganate, grass leaves and stems and the curettage [5] [11] [12] [13] [14]. The main complications in this series were anaemia $(62.1 \%)$ due to vagina bleeding, the endometritis (13.7\%) and the pelviperitonitis (6.9\%). Our results are comparable to those described in the literature where the bleeding predominates at a rate varying from 40 to $76.29 \%$ [14] [15] [16] [17]. This could be explained by the ignorance of the patients on the complications of abortion means and the massive use of the misoprostol which effect provider incomplete abortion thus hemorrhagic was established by the series of Mayi-Tsonga [17]. In Niger, the endometritis $(35.76 \%)$ was related as first complication of induced abortions [5]. In Ivory Coast, the chronic pelvic pains and the uterine perforation dominated the complications [12]. The complications are based on abortion mean used, aseptic conditions and the qualification of the person practicing abortion. The infectious complications (endometritis, pelviperitonitis and septicemia) represented $24 \%$ of cases. Studies led in Gabon, Niger, Cameroon and Madagascar find the infectious complications to $15.54 \%$ a $44.89 \%$ of patients [5] [10] [11] [18] [19]. These complications are due to endo-uterine maneuvers realized in the inappropriate aseptic conditions. We registered one case (1/94 case) of death or, lethality rate $2.1 \%$. This rate range in the fork of the rate from 1.7 to 15.6 reported by other African authors [5] [8] [9] [11] [14] [19].

\section{Conclusion}

The induced abortion is a frequent situation in the Chad and is cause of numerous complications. Greater awareness of the young people on the contraceptive methods and to the gravity of clandestine abortion, a restriction in the accessibility in misoprostol could reduce the recourse to the clandestine abortion and these complications.

\section{References}

[1] International Federation of Gynecology and Obstetrics (2014) Prevention of Unsafe Abortions and Their Consequences. International Journal of Gynecology \& Obstetrics, 126, 1-70.

[2] The world Health Organization (1997) Medical Methods for Termination of Pregnancy. Report of a WHO Scientific Group. World Health Organization Technical Report Series, 871, 1-110.

[3] Cleland, J.G., Ndugwa, R.P. and Zulu, E.M. (2011) Family Planning in Sub-Saharan Africa: Progress or Stagnation? Bull WHO, 89,137-143. https://doi.org/10.2471/BLT.10.077925

[4] Ministry of Economy and Plan (2015) Demographic Investigation, of Health, and in Multiple Indicators in the Chad (EDS-MICS) on 2014-2015. INSEED, Riyadh, 1-63.

[5] Nayama, M., Gallais, A., Wage, H., Garba, M., Idi, N., Djibrill, B. and Lucot, J.P. (2009) Complications of Illegal Abortions in a Reference Maternity of Niger. Re- 
trospective Study about 151 Cases. Black Africa Medicine, 56, 171-175.

[6] Sepou, A., Ngbalé, R., Yanza, M.C., Domandé-Modanga, Z. and NuembiI, E. (2004). Analysis of the Abortions in the Maternity of the Community Hospital of Bangui. Tropical Medicine, 64, 61-65.

[7] Laghzaoui, O. (2016) Inventory of Unsafe Abortions: Retrospective Study of 451 Cases Treated in Moulay Ismail Military Hospital of instruction, Meknes, Morocco. Pan African Medical Journal, 24, 83.

[8] Rakotondraisoa, J.M., Andrianampy, H.A., Rajaonarison, J.J.C. and Randriambelomanana, J.A. (2013) Complications of Illegal Abortion at Gynaecology and Obstetrics Befelatanana Teaching Hospital, Antananarivo. Madagascar Medicine Review, 3, 273-277.

[9] Andriamifidison, N.Z.R., Mandrosovololoma, V., Zoliniainarisoa, A.T., Rakotondrazanany, E., Rakotonirina, E.J. and Andriampanalinarivo, R. (2013) Clandestine Induced Abortions at Service of Gynecology and Obstetrics of Béfélatanana, Antananarivo in. Black Africa Medicine, 60, 163-168.

[10] Mayi-Tsonga, S., Diallo, T., Litochenko, O., Methogo, M. and Ndombi, I. (2009) Prevalence of Illegal Abortions in Libreville Hospital, Gabon. Bull SocPatholExot, 102, 230-232.

[11] Abauleth, R., N’Guessan, K., Kakou, C., Konan, K.J., Koffi, A. and Diebli, I. (2009) Prognosis of Abortum Uterine Perforations at University Teaching of Coccody, Abidjan, Ivory Coast. Black Africa Medicine, 56, 163-167.

[12] Bi Vroh, J.B., Tiembré, I., Attoh-Touré, H., EkraKouadio, D., Kouakou, L., Coulibaly, L., AndohKouakou, H. and Tagliante-Saracino, J. (2012) Epidemiology of Induced Abortion in Ivory Coast. Health Public, 24, 67-76.

[13] Akpadza, K., Agba, K., Tété, V., Baéta, S., Attignon, A. and Adabra, K. (2005) Knowledge and Practice of Contraception by Patients Admitted for Clandestine Inducted Abortions at the Gynaecology and Obstetrics Clinic the University Teaching Hospital Tokoin-Lomé Togo. Black Africa Medicine, 52, 345-351.

[14] Nlomé-Nzé, A.R., Picaud, A., Mbadinga, A., Ogowet, N. and Engongah-Beka, T. (1991) Clandestine Abortions at Libreville: Real Public Health Problem. Black Africa Medicine, 38, 223-227.

[15] Fourn, N.Y., Aguemon, B., Hounkponou, F., Kabibou, S., Ahodakin, M.M. and Fourn, L. (2014) Prevalence and Associated Factors of Induced Abortion in Parakou Secondary School (Benin). Black Africa Medicine, 61, 564-570.

[16] Fawole, A.A. and Aboyeji, A.P. (2002) Complications from Unsafe Abortion: Presentation at Ilorin, Nigeria. Nigerian Journal of Medicine, 11, 77-80.

[17] Mayi-Tsonga, S., Diallo, T. and Litovchenko, O. (2009) Compared Study of Clandestine Induced Abortions: Misoprostol versus Other Mean Abortions. Clinics in Mother and Child Health, 6, 11-14.

[18] Harioly Nirina, M.O.J., Rasolonjatovo, Y., Rakotoarivony, S.T., Andrianjatovo, J.J. and Rakotoambinina, B. (2009) Abortion-Related Pelvic Peritonitis: Therapeutic Feature and Patients' Ending. Review d Anesth-Rea and Emergency Medicine, 1, $1-3$.

[19] Takongmo, S., Nkwabong, E., Pisoh-Tanggnyin, C., Simeu, C., NdiOmgba, R. andFouda, B.F. (2010) Surgical Complications of Clandestine Abortions: About 51 Cases Observed in Two Hospitals of Yaoundé. Clinics in Mother and Child Health, 7, C101927. https://doi.org/10.4303/cmch/C101927 
Submit or recommend next manuscript to SCIRP and we will provide best service for you:

Accepting pre-submission inquiries through Email, Facebook, LinkedIn, Twitter, etc. A wide selection of journals (inclusive of 9 subjects, more than 200 journals)

Providing 24-hour high-quality service

User-friendly online submission system

Fair and swift peer-review system

Efficient typesetting and proofreading procedure

Display of the result of downloads and visits, as well as the number of cited articles Maximum dissemination of your research work

Submit your manuscript at: http://papersubmission.scirp.org/

Or contact ojog@scirp.org 